\title{
An Empirical Study on Paths to Develop Dynamic Capabilities: From the Perspectives of Entrepreneurial Orientation and Organizational Learning
}

\author{
(C) Higher Education Press and Springer-Verlag 2010
}

\begin{abstract}
Dynamic capabilities are regarded as a strategic premise to creating, maintaining and upgrading sustainable competitiveness. Considering organizational learning as a mediator variable, this study tests the relationship between entrepreneurial orientation and dynamic capabilities, and identifies paths to develop dynamic capabilities and the components of these capabilities. More specifically, the factor analysis method was employed to verify that dynamic capabilities are comprised of four dimensions, i.e. environmental sensing capabilities, change and renewal capabilities, technological and organizational flexibility capabilities. It was found that dimensions of entrepreneurial orientation have a significantly positive effect on dynamic capabilities to different extents, while organizational learning, which has significantly positive effect on dynamic capabilities, plays a partial mediating role between the two. These findings indicate that companies can build dynamic capabilities through different levels of organizational learning in the context of innovative and proactive atmosphere.
\end{abstract}

Keywords entrepreneurial orientation, organizational learning, dynamic

Translated and revised from Guanli Shijie 管理世界 (Management World), 2008, (4): 91-106

Hao Jiao $(\bowtie)$

School of Business, Fudan University, Shanghai 200433, China

E-mail: haojiao@ymail.com

Jiang Wei

School of Business, Zhejiang University, Hangzhou 310058, China

E-mail: weijiang@zju.edu.cn

Yu Cui

School of Business, Fudan University, Shanghai 200433, China

E-mail: cui.yu@ymail.com 
capabilities, mediation effect

\section{Introduction}

With an accelerating trend of global economic integration, market and industry environments tend to be more complicated, dynamic and uncertain, which lead to so called hyper-competition (D'Aveni, 1994). Globalization and technological innovation make competition fiercer; disintegration of original frameworks changes competition rules in many industries. As a result, markets become more complicated and unpredictable, which forces companies to sense their competitors' action and make corresponding response more quickly. Rapid changes make existing competitive advantage erode quickly. Competitive advantage has to be shaped through a new strategy (Griffith and Harvey, 2001).

In order to sense and seize the opportunities that a dynamic operating environment opens up, companies have to reconfigure their existing assets and processes. Managerial and technological capabilities can offer sustainable competitive advantage in rapidly changing markets only through sensing the tendency of the changes and understanding their consequences, and reconfiguring firm-specific resources and processes continuously to match environmental requirement. Thus, firms must have the dynamic ability to integrate, build, and reconfigure internal and external competences so as to change the operational capabilities to finally address rapidly changing environments (Teece et al., 1994, 1997, 2007; Zahra et al., 2006). The current dynamic capabilities theory is build upon the basic assumption of resource-based view, and reflects an organization's ability to achieve new and innovative forms of competitive advantage given path dependencies and market positions.

Recent research in dynamic capabilities theory mainly focus on the connotation and definition, components, constructing incentives, and influencing factors, which explain the operative mechanism of dynamic capabilities (Ianisti and Clark, 1994; Collis, 1994; Griffith and Harvey, 2001; Lawson and Samson, 2001; Zahra and George, 2002; Zollo and Winter, 1999; Zollo and Winter, 2002; Zott, 2003; Ambrosini and Bowman, 2009). However, as Zahra et al. (2006) criticized, current research in dynamic capabilities theory is lack of empirical test, ignoring whether entrepreneurship and organizational culture have effects on dynamic capabilities. Meanwhile, corporate entrepreneurship theory plays an increasingly important role in this area (Burgelman, 1983; Miller, 1983; Covin and Slevin, 1989, 1991; Lumpkin and Dess, 1996, 2001; Zahra et al., 1999).

Dynamic capabilities are the entrepreneurial ability to adapt to rapidly changing environment (Teece, 2007), therefore, entrepreneurial orientation, with the characteristics of innovativeness, proactiveness and risk-taking, has great 
impact on dynamic capabilities development (Lawson and Samson, 2001). Entrepreneurship can push knowledge to circulate, spread and transfer intra-organizationally and inter-organizationally, which finally foster the organizational capabilities (Zahra et al., 1999). Moreover, Tsoukas and Mylonopoulos (2004) also found that knowledge and learning play an important role in the development of dynamic capabilities.

This paper explores the relationships among entrepreneurial orientation, organizational learning and dynamic capabilities based on the above studies. Specifically, we examine how to develop dynamic capabilities through utilization of entrepreneurial orientation and continuous organizational learning in the context of China. In order to test the hypotheses, survey data of 108 firms were collected from the manufacturing and service sectors. The empirical findings indicate that entrepreneurial orientation and continuous organizational learning have positive effects on dynamic capabilities.

This paper is organized as follows: First, we elaborate on the theoretical background and propose research hypotheses, which is followed by the research methods, including sample, data collection and measures. Then, we discuss the empirical results. And a general discussion, conclusion and implications conclude.

\section{Literature Review and Hypotheses}

\subsection{Theoretical Framework}

Penrose (1959) proposed the growth theory of firm which emphasizes the importance of internal resources and inter-organizational learning to match external environment. Especially, as time goes by, competition among firms becomes more truculent, which pushes firms to train and enhance the capabilities of integrating, building, and reconfiguring internal and external resources to address the changing environment (Teece et al., 1997). Through this manner, these capabilities change the existing operational mechanism in order to satisfy new customers and markets, and finally improve performance. In order to explain the effect of dynamic capabilities on competitive advantage, Teece et al. (1994, 1997, 2007), Eisenhardt and Martin (2000), Helfat and Peteraf (2003), Zahra et al. (2006) discussed the connotation and relationship between organizational learning and dynamic capabilities from the perspective of process, routine, and knowledge management. Cepeda and Vera (2007) discussed the mechanism of how to apply dynamic capabilities to operational capability from the perspective of knowledge management. Tsoukas and Mylonopoulos (2004) considered organization as a knowledge system. The relationship between 
knowledge, learning and dynamic capabilities were discussed, and the viewpoint of enhancing dynamic capabilities through creating new knowledge by continuous learning and then dispersed knowledge into organizational level were raised.

Meanwhile, an increasing number of firms try to employ entrepreneurial orientation to develop dynamic capabilities. For example, Jantunen et al. (2005) used survey data in the manufacturing and service sectors and explored the relationship among entrepreneurial orientation, reconfiguring capabilities and performance. The empirical findings indicated that entrepreneurial orientation and reconfiguring capabilities had positive effect on international performance. Therefore, we develop the relationship framework among entrepreneurial orientation, organizational learning and dynamic capabilities and raise the hypotheses as described in Fig. 1.

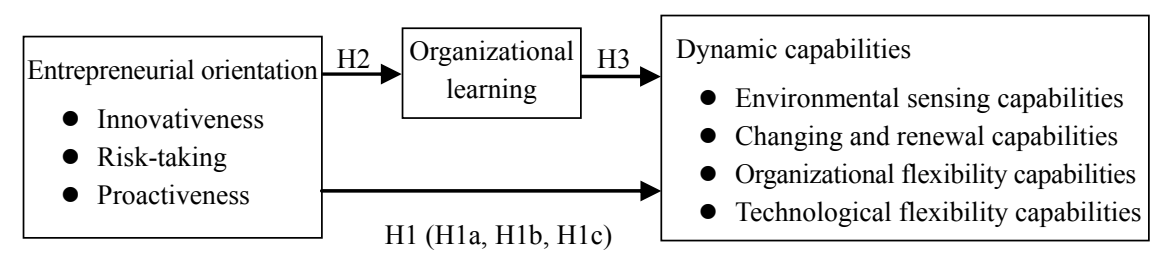

Fig. 1 Conceptual Model and Hypothesized Relationships

\subsection{Variable Description}

\subsubsection{Entrepreneurial Orientation}

Entrepreneurial orientation originates from the research on strategic decision-making model in the field of strategic management, which can be traced back to strategic choice theory emphasizing that firms analyze market firstly, then make strategic decisions, and finally enter the new market with the effective method (Covin and Slevin, 1989). Therefore, entrepreneurial orientation not only describes a mindset in response to environmental change and starting new business, but also provides a useful framework to analyze entrepreneurship atmosphere within an organization (Lumpkin and Dess, 1996, 2001). Entrepreneurial orientation can exist in all kinds of organizations emphasizing innovation through learning based on the existing resources.

On the one hand, corporate entrepreneurship can be used to refer to the process of creating new start-ups in existing company so as to improve organizational capabilities and enhance competitiveness (Zahra et al., 1999). On the other hand, corporate entrepreneurship can create new culture by means of internal innovation, joint ventures, and cooperation on the basis of existing organizations resources (Dess et al., 2003). Therefore, entrepreneurial orientation can be 
measured by autonomy, innovativeness, risk-taking, proactiveness and competition initiative (Lumpkin and Dess, 1996). More specifically, a business firm characterized by innovativeness, risk-taking and proactiveness can be considered as an entrepreneurial orientation firm (Covin and Slevin, 1989). Drawing on the existing literature, innovativeness, risk-taking and proactiveness are used in this study to measure entrepreneurial orientation (Naman and Slevin, 1993; Zahra and Covin, 1995; Covin, Green and Slevin, 2005; Wiklund and Shepherd, 2005).

\subsubsection{Organizational Learning}

Argyris and Schon (1978) focused on organizational members and defined organizational learning as a process of detecting errors and anomalies by members in organization, through which could remodel and amend organizational action. Organizational learning can be considered as the actions to explore or develop relevant skills and knowledge based on experiences and activities in the past, and uses these skills and knowledge in subsequent operations, in order to enhance the competitiveness of the organization and performance (Fiol and Lyles, 1985).

Huber (1991) classified organizational learning processes from the "knowledge" perspective. He distinguished four stages of organizational learning: knowledge access, knowledge distribution, knowledge interpreting, and memory organizing. Therefore, knowledge is the foundation of learning, and organizational learning is on behalf of combination of all knowledge generated, including four stages of knowledge generation, refining, promotion and diffusion (Bontis, 1998). Further, Crossan et al. (1999) studied the relationship between the five levels in learning system. They also drew an evaluation chart of the strategic learning by sorting all levels of learning. The chart includes three learning stocks (i.e. individual learning, group learning and organizational learning) and two learning flows (i.e. feedforward learning layer and feedback learning layer). Organizational learning is an interaction between learning stocks and learning flows.

In sum, this study considers organizational learning as a dynamic process of strategic transformation occurring across three levels of the organization: individual, team and organization. The knowledge and skills of the individual will be transferred or diffused into team or organization level. At the same time, the knowledge at the team or organization level will be disseminated to other individuals.

\subsubsection{Dynamic Capabilities}

Scholars have conducted research on dynamic capabilities from different 
perspectives, which has lead to some disparities in the denotative sense of the term "dynamic capabilities". Early definitions of dynamic capabilities were mostly descriptive, hypothesizing that dynamic capabilities are the source of competitive advantages. For example, dynamic capabilities can be referred to the capabilities of enterprises to integrate, develop and reconfigure internal and external competences so as to address rapidly changing environments (Teece et al., 1997; Griffith and Harvey, 2001).

In order to interpret how effectively dynamic capabilities affect competitive advantage, some researchers have explored the operational mechanisms of dynamic capabilities. For example, dynamic capabilities can select the technical knowledge associated with their existing knowledge foundations during the evolution of their business and technical models of operation to dynamically improve existing activities (Collis, 1994; Ianisti and Clark, 1994; Eisenhardt and Martin, 2000; Lawson and Samson, 2001; Zahra \& George, 2002; Zollo and Winter, 2002; Helfat and Peteraf, 2003; Winter, 2003; Zahra et al., 2006). These researchers highlighted the updating and flexible features of innovation and eliminated synonymic repetition in definitions of dynamic capabilities.

As above mentioned, dynamic capabilities are regarded as composed of four components: (1) environmental sensing capabilities (Prahalad and Hamel, 1990; Lawson and Samson, 2001; Li, 2006); (2) change and renewal capabilities (Collis, 1994; Teece et al., 1997; Zollo and Winter, 2002; Helfat and Peteraf, 2003; Zahra et al., 2006); (3) technological flexibility capabilities (Ianisti and Clark, 1994; Collis, 1994); and (4) organizational flexibility capabilities (Chandler, 1962; Nelson and Winter, 1982; Zollo and Winter, 1999). Respectively, these capabilities show the ability to sensitively respond to and identify changes in industries, the competence to innovate and transform, and the flexibility in technology and organizational structure.

Environmental sensing capabilities. Top managers and technical experts understand market development opportunities deeply. This point has been mentioned by Prahalad and Hamel (1990); they emphasized that companies should deepen their understanding of laws in industries and seize upon changing trends. Lawson and Samson (2001) also believed that intelligence system was one element of dynamic capabilities. Li (2006) found that all activities undertaken by companies to adapt to environmental changes first came originally from the capabilities to sufficiently sense the environment. The critical part of environment insight capabilities lies in recognition of consequences caused by environmental changes.

Change and renewal capabilities. Collis (1994) argued that the capabilities to integrate resources are valuable. Teece et al. (1997) pointed out that dynamic capabilities are not only capable of developing, configuring and integrating 
resources, but also integrating, innovating and updating operational process. Zollo and Winter (2002), and Helfat and Peteraf (2003) also indicated that dynamic capabilities are those to correct operations, so as to adapt to changing environments.

Technological flexibility capabilities. According to Ianisti and Clark (1994), it is critically important that existing technologies shall be rapidly improved to meet needs of customers based on a given products and/or services. Companies should be able to select from the technical knowledge associated with their existing knowledge foundations during relevant evolutionary stage in order to execute this kind of association. The ability to compete at the new level of technology is based on its capabilities in a previous version of that technology. Collis (1994) further argued that current technology should be functionally favorable for increasing new product lines and services.

Organizational flexibility capabilities. Organizational flexibility capabilities refer to the organizational structure's attributes that concern the procedure of decision-making authority, duty configuration and information flow. Chandler (1962) proposed that organizational structure should follow strategy. In this sense, the execution of strategies requires that companies allow different departments to break through formal procedures so as to maintain working flexibility and dynamics. Therefore, companies that support organizational flexibility are always faster than competitors. Zollo and Winter (1999) argued that organizational structure should be flexible, so as not to petrify organizational routines.

To summarize, firms have to orient to customers at any given moment, strive for targets that promote values and satisfy customer demands, and rely on environment sensing capabilities and rapid response capabilities so that they may dynamically adapt to complicated changes of external environment. Ultimately, such companies can realize the best match between resources and dynamic environments. By innovating and updating dynamics, such companies gain information from environmental changes, configure and integrate resources through technology and organizational flexibility capabilities, and thereby achieve sustainable competitiveness.

\subsection{Entrepreneurial Orientation and Dynamic Capabilities}

With the changes in dynamic environment, more firms have employed entrepreneurial orientation with the characteristics of innovativeness, risk-taking and proactiveness (Miller, 1983; Covin and Slevin, 1991; Lumpkin and Dess, 1996). In this sense, dynamic capabilities can be cultivated, with the gain of competitiveness. Wiklund (1999) found that entrepreneurial orientation has an essential effect on organizational culture, internal operation process, organizational learning and capabilities improvement. Therefore, entrepreneurship strategy is 
becoming the key choice in response to complex environment as well as managerial transformation (Zahra et al., 2006). Besides, higher level of entrepreneurial orientation supports the capabilities of discovering opportunities, which will have a positive effect on dynamic capabilities (Jantunen et al., 2005). Generally, entrepreneurial oriented firms can create, define, discover and exploit new market opportunity earlier than competitors (Hamel and Prahalad, 1994; Miller, 1983). Moreover, Subba and Narasimha (2001) revealed a positive effect of entrepreneurial orientation on dynamic capabilities, which indicated that entrepreneurial organization would help form dynamic capabilities.

Most importantly, senior manager is the specific implementation unit of entrepreneurial orientation. Creative ideas, personal preferences, skills and experience, the tolerance for change, and capacity to implement change will affect the ability to adapt to environmental change. Sirmon and Hitt (2003) pointed out that entrepreneur and members of high management team were the key agents for change. When surrounded by changes, these people will activate dynamic capabilities embedded in organizational process, strip redundant resources which are not fit to complex environment, and finally reconfigure resources to develop capabilities in order to cater to the existing and new market. We thus develop hypothesis 1 as follows:

H1 Entrepreneurial orientation has a positive relationship with dynamic capabilities.

In recent years, many scholars have elaborated on multi-dimension and independence of each dimension of entrepreneurial orientation, and considered entrepreneurial orientation as a multi-dimensional construct (Covin and Slevin, 1989; Lumpkin and Dess, 1996; Wiklund, 1999). Lumpkin and Dess (1996) believed that one single dimension can not reflect particular contribution of each component of entrepreneurial orientation. They considered that three dimensions of innovativeness, risk-taking and proactiveness of entrepreneurial orientation are correlated, but relatively independent from each other. That is to say, the components of entrepreneurial orientations do not necessarily change in the same direction. Different dimensions of entrepreneurial orientation should not be co-varying as well. Generally, if any one or two dimensions of entrepreneurial orientation, namely innovativeness, risk-taking or proactiveness are powerful, we think that a company is entrepreneurial-oriented. Morris and Kuratko (2001) also showed that dimensions of entrepreneurial orientation in the form of different combinations were possible.

In all, differences in industry, market position and social culture cause dimensions of entrepreneurial orientation such as innovativeness, risk-taking, and proactiveness to be independent from one another. Some firms can employ 
continuous product and market innovation to achieve competitiveness, others may adapt risk-taking strategy to get above-average benefit, and still others can seize upon opportunities to get first-mover benefit. Therefore, we suggest the following hypothesis $1 \mathrm{a}, 1 \mathrm{~b}$, and $1 \mathrm{c}$ :

H1a The innovative dimension of entrepreneurial orientation has a positive relationship with dynamic capabilities.

H1b The risk-taking dimension of entrepreneurial orientation has a positive relationship with dynamic capabilities.

H1c The proactive dimension of entrepreneurial orientation will has a positive relationship with dynamic capabilities.

\subsection{Entrepreneurial Orientation and Organizational Learning}

Based on the model of entrepreneurship, knowledge and organizational capabilities development raised by Zahra et al. (1999), Dess et al. (2003) tested the relationship among corporate entrepreneurship strategy, organizational learning and knowledge. They discussed how entrepreneurship had the effect on organizational learning. Innovative atmosphere in organization has a positive effect on organizational learning. Sambrook and Roberts (2005) believed that successful entrepreneurial activities with knowledge intensive characteristics pushed a learning process.

Based on learning theory and behavior science, Zahra et al. (2006) discussed learning situation in the background of entrepreneurial orientation. They found that firms with characteristics of entrepreneurial orientation would promote mutual learning in same department and among different departments, in which the member would remove ideological package and share knowledge with others. We, therefore, propose Hypothesis 2:

H2 Entrepreneurial orientation has a positive relationship with organizational learning.

\subsection{Organizational Learning and Dynamic Capabilities}

Organizational learning is important to capabilities accumulation. It is not important for firms to accumulate the knowledge through static focus, but for transfer and creation of the new knowledge through dynamic focus (Nonaka and Takeuchi, 1995). Dynamic capabilities mean to create, accept and implement the new idea, new process, new product and service. When a firm is full of learning atmosphere, it becomes easier for it to adapt to complicated environment. Zollo and Winter (1999) found that dynamic capabilities came from interaction among three learning mechanisms such as tacit knowledge accumulation, knowledge articulation, and knowledge codification processes. Eisenhardt and Martin (2000) 
also believed that learning mechanism not only guide the evolution and enhancement of dynamic capabilities. It is consist of the basis of path dependency. Subba and Narasimha (2001) found that organizational design and learning, and human resources management will promote the formation of dynamic capabilities.

In a later research, Zollo and Winter (2002) investigated the mechanisms through which organizations develop dynamic capabilities, summarized as routinized activities directed to development and adaptation of operational routines, and reflected by the role of experience accumulation, knowledge articulation and knowledge codification processes. They argued that dynamic capabilities are shaped by the co-evolution of these learning mechanisms. At any point in time, firms adopt a mix of learning behaviors constituted by a semi-automatic accumulation of experience and by deliberate investments in knowledge articulation and codification activities. Therefore, dynamic capabilities derive from highly deliberate learning processes. That is to say, organizational learning, which improves the organizational routines systematically and promotes the evolution of organizational capabilities, is a source of dynamic capacities.

Generally speaking, organizational learning begins with sensing opportunity from external environment at the individual level. Learning agents generate good ideas that change the existing technology and organizational structure to adapt the change through individual level learning, group level learning, organizational level learning, forward level learning, and feedback level learning in process of dissemination, reproduction, proliferation and institutionalization in whole organization to respond to changing environment (Calantone et al., 1979) .We thus raise Hypothesis 3:

H3 Organizational learning has a positive relationship with dynamic capabilities.

2.6 The Mediating Role of Organizational Learning in the Relationship between Entrepreneurial Orientation and Dynamic Capabilities

As discussed above, entrepreneur and members of the high management team must respond quickly to environment changes. However, the responding procedure and solution may be not in existing routines, which need to be created according to new situation (Christensen and Raynor, 2003; Miller, 1983). Firms must develop new method to respond change through implicit learning, improvisation learning, learning by action, and learning by trial and error (Eisenhardt and Tabrizi, 1995). Organizational learning can be considered as a heterogeneous resource to create competitive advantage (Crossan and Nicolini, 2000). Furthermore, entrepreneurship can push knowledge transfer and diffusion, 
promote organizational acquisitive learning and experimental learning, and ultimately put forward the enhancement of organizational capabilities (Zahra et al., 1999). Thus, capabilities accumulation is driven by organizational learning and molded by path dependencies, complementary assets, and industry opportunities (Teece et al., 1997). This approach emphasizes that it is not only the bundle of resources which matters but also the mechanisms through which firms accumulate these skills and contingencies which constrain their direction.

According to the dynamic capabilities theory, firms accumulate knowledge, expertise, and skills through organizational learning. Learning enables firms to perform their activities in better ways. Organizational learning is not limited to internal activity but also results from assimilating and utilizing knowledge generated outside the firm from the networking. Thus, firms must deeply understand the effect of entrepreneurial orientation and organizational learning on dynamic capabilities. We thus develop hypothesis 4 as follows:

H4 The positive relationship between entrepreneurial orientation and dynamic capabilities is mediated by organizational learning.

\section{Methods}

\subsection{Sample and Data Collection}

This study is a retrospective study with high-tech and knowledge-intensive business firms as samples at the preliminary stage of our study. $61.11 \%$ of the samples are high-tech and knowledge-intensive business firms. Most of them are from the Yangtze River Delta region such as Shanghai and Hangzhou and so on.

As many of the questionnaire items involve the circumstances and details about sample firms' policies and strategies, it is necessary for these firms' executive officers (or senior managers such as presidents, vice-presidents, directors, or general managers) to complete the questionnaire themselves (Phillips, 1981). In other words, the respondents should be aware of their firms' operation details or relevant policies. An important step in the data collection process is gaining direct access to the firm's original entrepreneur(s) or executive officer(s). This allows us to conduct in-depth interviews in addition to the commonly-adopted standard paper survey. In doing so, we collected more basic information regarding the firm and its history. Personal interviews also help improve the reliability of our survey data.

\subsection{Measures}

Given the exploratory nature of this study, measurements were developed in the following ways: as mentioned above, because the variables such as 
entrepreneurial orientation and organizational learning have been employed in previous studies, the measures were adopted as long as they could provide acceptable measurement quality with minor modification in wording to increase their applicability to the Chinese context. In other words, for a scale to be used, particular attention is paid to translate the original version of the scale to capture its linguistic nuances. For example, the Organizational Learning Scale is firstly translated into Chinese and then translated back into the original language by another translator in order to verify that the meaning of questions is maintained. All of the scales used in this study adopted the form of Likert and semantic-differential scales.

\subsubsection{Control Variables}

There are firm-specific and external factors that may affect a firm's dynamic capabilities, regardless of its entrepreneurial orientation or organizational learning level (Teece, 2007). We hence control for ownership, industry and age.

\subsubsection{Independent Variable: Entrepreneurial Orientation}

The concept of entrepreneurial orientation encapsulates firm-level processes, practices, routines, decision-making style (Lumpkin and Dess, 1996), and strategic orientation (Wiklund and Shepherd, 2003) of an entrepreneurially-oriented firm. This variable was measured with a nine-item scale adopted from relevant study of Khandwalla (1977), Miller and Friesen (1982), Covin and Slevin (1989), Naman and Slevin (1993), and Wiklund (1999). The degree of entrepreneurial orientation could be referred to the extent to which firms innovate, take risks, and are proactive. Entrepreneurial orientation was measured by nine items (a 5-point Likert scale) that tap into attitudes towards innovativeness, risk-taking propensity and proactiveness using. For each of the nine items, the respondents were asked to indicate the extent to which their firms met the situation described in each question during the previous three years.

\subsubsection{Mediator Variable: Organizational Learning}

This study's measurement of organizational learning is consistent with research conducted by Sinkula et al. (1997), Hult et al. (1997), Goh and Richards (1997), and Baker and Sinkula (1999). All of scales used to measure organizational learning (OL) have their origins in Bontis et al. (2002), which are defined with fifty items distributed in five dimensions: learning stocks of individual (II), group (GG) and organizational (OO); and learning flows of feedforward (FF) and feedback (FD). 


\subsubsection{Dependent Variable: Dynamic Capabilities}

This study's measurement of dynamic capabilities is consistent with research conducted by Teece et al. (1997), Zahra et al. (2006), and Teece (2007). Participating CEOs or senior managers were asked to recall their strategy circumstances during the process of a free response. Then questions based on semantic differential scales were employed to provide additional assessments. There has been a large amount of research considering dynamic capabilities as dependent variable. For example, Jantunen et al. (2005) measured dynamic capabilities with quantity of reconfiguring activities in past three years. Caloghirou et al, (2004) measured dynamic capabilities with learning, coordinative and innovative capabilities. Li (2006) suggested that dynamic capabilities could be measured with environment insight capabilities, configuration and integration capabilities. He et al. (2006) believed that dynamic capabilities emphasize knowledge accumulated in response to market changes. Cepeda and Vera (2007) proposed a concept of knowledge reconfiguration capabilities to measure dynamic capabilities. In this study, dynamic capabilities are measured with a fifteen-item scale developed based on relevant research (e.g., Teece et al. 1994, 1997, 2007; Lawson and Samson, 2001; Jantunen et al., 2005; Zahra et al., 2006; Cepeda and Vera, 2007).

Dynamic capabilities were divided in this study into four dimensions, including environmental sensing capabilities, change and renewal capabilities, technological and organizational flexibility capabilities. Fifteen items were used to measure dynamic capabilities. Environmental sensing capabilities were measured by three aspects of "recognition of industry laws", "advance response to environmental changes", and "interaction with interested parties", changing and renewal capabilities by "innovation supporting policies", "innovation-oriented enterprise cultures", "awards to employees for innovation", "employee creations" and "adventuring and initiating employees", and technological flexibility capabilities by "the respective effects of existing technologies on existing product lines, existing products, and existing customers". Organizational flexibility capabilities were measured by "working flexibility", "working modes", "communication channels", and "speeds of strategic transfers".

\subsection{Common Method Bias Test}

To avoid common method bias, the study uses the Harman one-factor test to examine the possible existence of common method variance. One method to eliminate common method variance is to improve prevention in advance as much as we can. In this study, we take method of concealing the personal information 
of respondents. Podsakoff and Organ (1986) believed that significant common method variance would result if one general factor accounts for the majority of covariance in the variables. Therefore, we employed the Harman principal factor analysis to check possible existence of common method variance. We followed the Podsakoff and Organ's (1986) suggestion, and conducted a principal factor analysis of the questionnaire measurement items of this study without varimax rotation, in which the first factor with eigenvalues greater than 1 accounts for $39.949 \%$ of the total variance. Since a single factor does not emerge and one general factor does not account for most of the variance, common method bias is unlikely to be a serious problem in the data.

\section{Results}

\subsection{Reliability and Validity Testing}

In the study, we employed the Cronbach's alpha to test reliability (Nunnally, 1978; Churchill and Peter, 1984). To assess the reliability of the scale in entrepreneurial orientation (EO), a principal components factor analysis with varimax rotation with Kaiser Normalization was performed on the nine items. The analysis revealed that two distinct factors explain approximately $70.938 \%$ of the total variance and corresponding with innovativeness and proactiveness strategy (INP), and risk-taking strategy (RI), respectively. The result shows that coefficients of Cronbach's alpha in innovativeness and proactiveness strategy and risk-taking strategy are satisfactory (Cronbach's alpha is 0.898 and 0.876 respectively).

To assess the reliability of the scale in dynamic capabilities (DY), a principal components factor analysis with varimax rotation with Kaiser Normalization was performed on fifteen items. The factor analysis revealed the four distinct factors explain approximately $67.28 \%$ of the total variance and corresponding with environmental sensing capabilities (EN), change and renewal capabilities $(\mathrm{CH})$, technological flexibility capabilities (TE), and organizational flexibility capabilities (OR), respectively. The coefficients of Cronbach's alpha in four components of dynamic capabilities were satisfactory (Cronbach's alpha is 0.755 , $0.804,0.817$ and 0.776 respectively).

For all measurement specifications, standardized factor loading should exceed the accepted threshold value of 0.707 (Carmines and Zeller, 1979; Shimp and Sharma, 1987). However, various researchers believe that this rule of thumb should not be so inflexible and such a limit may be appropriately enlarged, and 0.650 may be taken as minimum standard (Barclay et al., 1995; Chin, 1998). Results showed that the minimum loading of standardized factor in measurement specifications was higher than 0.650 , the minimum requirement, exhibited higher 
statistic prominence $(p<0.005)$. This result indicates extremely convergent validity of the constructs in the study.

Moreover, all of constructs are reliable as they present values for composite reliability greater than the value of 0.700 , as required in the research. Meanwhile, the average variance extracted (AVE) of each construct should be greater than 0.500 , meaning that $50 \%$ or more variance of the indicators should be accounted for (Fornell and Larcker, 1981). The AVE of all constructs in our model exceeds 0.606.

The constructs also exhibit relatively high discriminant validity. For discriminant validity, we have compared the square root of the AVE (average variance extracted) with the correlations among constructs. According to Fornell and Larcker (1981), in order to ensure that various constructs differ in connotation and cases, the AVE square root of each construct in the models shall be higher than the relevant coefficient between such a construct and other constructs. On average, each construct relates more strongly to its own measures than to others, providing an estimate of discriminant validity of the constructs in our study.

\subsection{Analysis and Results}

The study attempts to understand the relationships among entrepreneurial orientation, organizational learning, and dynamic capabilities. Table 1 reports the means, standard deviations, and correlations of all variables. According to Belsley, kuh and Welsch's (1980) criterion, none of the regression models has problem of Multi-Collinearity $(0<$ VIF (variance inflation factor) $<10$ and CI (condition index) $<30$ ). In the following paragraphs, empirical results of regression analysis will be presented in detail.

Table 1 Descriptive Statistics and Correlations

\begin{tabular}{|c|c|c|c|c|c|c|c|c|}
\hline Variables & Mean & S.D. & 1 & 2 & 3 & 4 & 5 & 6 \\
\hline 1. Ownership & 2.06 & 0.998 & & & & & & \\
\hline 2. Industry & 1.55 & 0.500 & -0.053 & & & & & \\
\hline 3. Age & 3.05 & 1.027 & -0.149 & -0.086 & & & & \\
\hline $\begin{array}{l}\text { 4. Innovativeness } \\
\text { and } \\
\text { proactiveness }\end{array}$ & 3.229 & 1.029 & -0.046 & 0.093 & -0.040 & & & \\
\hline 5. Risk-taking & 3.043 & 1.111 & 0.031 & -0.060 & -0.035 & $0.502 * * *$ & & \\
\hline $\begin{array}{l}\text { 6. Organizational } \\
\text { learning }\end{array}$ & 3.612 & 0.626 & 0.119 & 0.159 & -0.047 & $0.704 * * *$ & $0.505 * * *$ & \\
\hline $\begin{array}{l}\text { 7. Dynamic } \\
\text { capabilities }\end{array}$ & 3.701 & 0.561 & 0.210 & 0.124 & 0.155 & $0.568 * * *$ & $0.307 * *$ & $0.774 * * *$ \\
\hline
\end{tabular}

Note: $N=108$ (two-tailed test).

$* * *, * *$ and $*$ indicate significant at the $0.001,0.01,0.05$ level, respectively (2-tailed). 


\subsubsection{Empirical Results: Dynamic Capabilities on Entrepreneurial Orientation}

Table 2 displays the results of ordinary-least-square regression analysis of the effects of entrepreneurial orientation on dynamic capabilities. Model 1 is the base model that includes the control variables such as age, industry and ownership. Model 2 captures the effects of entrepreneurial orientation, including innovativeness and proactiveness strategy and risk-taking strategy, on dynamic capabilities, which are significant at the $p<0.001$ level $\left(R^{2}=0.360\right)$. Compared with base model (Model 1), Model 2 explained more variance in dynamic capabilities. The adjusted $R^{2}$ is increase from 0.022 to 0.332 . And also, $\mathrm{F}$ of the Model 2 is 10.01 and significant at the $p<0.001$ level. Therefore, we can conclude that entrepreneurial orientation has the positive effect on dynamic capabilities generally. Specifically, the relationship between innovativeness and proactiveness strategy and dynamic capabilities is significant at the $p<0.001$ level. Coefficient of innovativeness and proactiveness strategy is positive and significant for dynamic capabilities $(\beta=0.531, p \leqslant 0.001)$. However, the relationship between risk-taking strategy and dynamic capabilities is not significant. These findings support the $\mathrm{H} 1, \mathrm{H} 1 \mathrm{a}$, and $\mathrm{H} 1 \mathrm{~b}$, indicating that, in general, business firms would achieve a higher degree of dynamic capabilities during their survival and growth stages. In a rapidly changing environment, if firms invest more in building up its innovativeness and proactiveness strategy and give their employees more autonomy to be innovative and proactive.

Table 2 Empirical Results: Dynamic Capabilities and Organizational Learning on Entrepreneurial Orientation

\begin{tabular}{|c|c|c|c|c|}
\hline \multirow[t]{2}{*}{ Variables } & \multicolumn{2}{|c|}{ Dynamic capabilities } & \multicolumn{2}{|c|}{ Organizational learning } \\
\hline & Model $1(\beta)$ & Model $2(\beta)$ & Model $3(\beta)$ & Model $4(\beta))$ \\
\hline \multicolumn{5}{|l|}{ Control variables } \\
\hline Ownership & 0.174 & 0.129 & 0.121 & 0.071 \\
\hline Industry & $0.068^{*}$ & 0.035 & 0.110 & 0.084 \\
\hline Age & -0.144 & -0.126 & -0.030 & 0.002 \\
\hline \multicolumn{5}{|l|}{ Independent variables } \\
\hline Innovative and proactiveness & & $0.531 * * *$ & & $0.587 * * *$ \\
\hline Risk-taking & & $0.039^{\mathrm{ns}}$ & & $0.211 * *$ \\
\hline \multicolumn{5}{|l|}{ Results } \\
\hline$F$ & $2.140^{*}$ & $11.396^{* * *}$ & $0.950^{*}$ & $22.974 * * *$ \\
\hline$R^{2}$ & 0.058 & 0.360 & 0.027 & 0.537 \\
\hline Adjusted $R^{2}$ & 0.022 & 0.322 & 0.001 & 0.514 \\
\hline$R^{2}$ change & \multicolumn{2}{|c|}{0.300} & \multicolumn{2}{|c|}{0.513} \\
\hline
\end{tabular}

Note: ns means correlation is not significant. ${ }^{* * *}, * *$ and $*$ indicate significant at the 0.001 , 0.01, 0.05 level, respectively (2-tailed). 


\subsubsection{Empirical Results: The Effect of Entrepreneurial Orientation on Organizational Learning}

Table 2 also displays the results of ordinary-least-square regression analysis of the effects of entrepreneurial orientation on organizational learning. Model 3 is the base model that includes the control variables such as age, industry and ownership. Model 4 in Table 2 demonstrates the relationship between entrepreneurial orientation and organizational learning. The Model is significant at the $p<0.001$ level $\left(R^{2}=0.537\right)$. Compared with base model (Model 3), explanation of Model 4 to dynamic capabilities is increasing. The adjusted $R^{2}$ increases from 0.001 to 0.514 . And also, F of the Model 4 is 22.974 and significant at the $p<0.001$ level. Therefore, we can conclude that entrepreneurial orientation has the positive effect on organizational learning as a whole. In addition, two dimensions of entrepreneurial orientation, namely innovativeness and proactiveness strategy $(\beta=0.587, p \leqslant 0.001)$, and risk-taking strategy $(\beta=0.211, p \leqslant 0.01)$, have positive and significant effects on organizational learning. These findings support $\mathrm{H} 2$ and indicate that innovativeness and proactiveness strategy is more favorable than risk-taking strategy in promoting organizational learning.

\subsubsection{Empirical Results: The Effect of Organizational Learning on Dynamic Capabilities}

We hypothesize that organizational learning would have a positive effect on dynamic capabilities. Model 5 is the base model that includes the control variables such as age, industry and ownership. Model 6 in Table 3 presents the effect of organizational learning on dynamic capabilities. The Model is significant at the $p<0.001$ level $\left(R^{2}=0.621\right)$. Compared with base model (Model 5), Model 6 explains more variance in dynamic capabilities. The adjusted $R^{2}$ increases from 0.029 to 0.605 . In addition, $F$ of the Model 6 is 40.902 and significant at the $p<0.001$ level. Therefore, we conclude that organizational learning has a positive effect on dynamic capabilities. Coefficient of organizational learning is positive and significant for dynamic capabilities $(\beta=0.761, p \leqslant 0.001)$, which indicates that companies would get a better dynamic capabilities when members of the company learn and communicate with each other more frequently and effectively. Accordingly, H3 is supported. 
Table 3 Empirical Results: Dynamic Capabilities on Organizational Learning

\begin{tabular}{|c|c|c|}
\hline \multirow[t]{2}{*}{ Variables } & \multicolumn{2}{|c|}{ Dynamic capabilities } \\
\hline & Model $5(\beta)$ & Model $6(\beta)$ \\
\hline \multicolumn{3}{|l|}{ Control variables } \\
\hline Ownership & 0.172 & 0.081 \\
\hline Industry & 0.062 & -0.022 \\
\hline Age & -0.144 & -0.121 \\
\hline \multicolumn{3}{|l|}{ Independent variables } \\
\hline Organizational learning & & $0.761 * * *$ \\
\hline \multicolumn{3}{|l|}{ Results } \\
\hline$F$ & 2.037 & $40.902 * * *$ \\
\hline$R^{2}$ & 0.057 & 0.621 \\
\hline Adjusted $R^{2}$ & 0.029 & 0.605 \\
\hline$R^{2}$ change & \multicolumn{2}{|c|}{0.576} \\
\hline
\end{tabular}

\subsubsection{Empirical Results: The Mediating Effect of Organizational Learning}

We also expect that organizational learning would mediate the relationship between the independent variable (entrepreneurial orientation) and the dependent variable (dynamic capabilities). Table 4 displays the results of ordinary-least-square regression analysis of the mediating effect of organizational learning between the relationship of entrepreneurial orientation and dynamic capabilities. Following Baron and Kenny's (1986) procedure, we firstly examine the relationship between the independent variable and the dependent variable. As shown in Table 4, only the innovativeness and proactiveness strategy is significantly related to dynamic capabilities. Secondly, as demonstrated in Table 4, significant relationships exist among innovativeness and proactiveness strategy and risk-taking strategy, and the mediator, organizational learning. Finally, the mediator, organizational learning, is included in the model to examine whether it reduces the effects of the antecedents to non-significant. The results in Table 4 show that the effect of innovativeness and proactiveness strategy to dynamic capabilities is significantly reduced. And it is not significant at all. Moreover, the mediator, organizational learning, is also significant at the level of $p<0.001$. The overall fit of the model is also improved. These findings support $\mathrm{H} 4$ and indicate that organizational learning plays a mediating role between innovativeness and proactiveness strategy and dynamic capabilities. Accordingly, $\mathrm{H} 4$ is supported. 
Table 4 Empirical Results: The Mediation Effect of Organizational Learning

\begin{tabular}{|c|c|c|c|c|}
\hline Step & Explanatory variable & $\begin{array}{l}\text { Explained } \\
\text { variable }\end{array}$ & $\beta$ & Conditions \\
\hline \multirow[b]{2}{*}{ Step 1} & Independent variables & $\begin{array}{l}\text { Dependent } \\
\text { variables }\end{array}$ & $\beta 1-1, \beta 1-2$ & $\beta 1$ should be significant \\
\hline & $\begin{array}{l}\text { Innovative and } \\
\text { proactiveness } \\
\text { risk-taking }\end{array}$ & $\begin{array}{l}\text { Dynamic } \\
\text { capabilities }\end{array}$ & $\begin{array}{l}0.531 * * * \\
0.039\end{array}$ & \\
\hline \multirow[b]{2}{*}{ Step 2} & Independent variables & $\begin{array}{l}\text { Mediator } \\
\text { variable }\end{array}$ & $\beta 2-1, \beta 2-2$ & $\beta 2$ should be significant \\
\hline & $\begin{array}{l}\text { Innovative and } \\
\text { proactiveness } \\
\text { risk-taking }\end{array}$ & $\begin{array}{l}\text { Organizational } \\
\text { learning }\end{array}$ & $\begin{array}{l}0.587 * * * \\
0.211 * *\end{array}$ & \\
\hline \multirow{4}{*}{ Step 3} & Independent variables & $\begin{array}{l}\text { Dependent } \\
\text { variables }\end{array}$ & $\beta 3-1, \beta 3-2$ & $\begin{array}{l}\beta 4 \text { should be significant } \\
\beta 1>\beta 3\end{array}$ \\
\hline & $\begin{array}{l}\text { Innovative and } \\
\text { proactiveness } \\
\text { risk-taking }\end{array}$ & $\begin{array}{l}\text { Dynamic } \\
\text { capabilities }\end{array}$ & $\begin{array}{r}0.079 \\
-0.113\end{array}$ & $\begin{array}{l}0.531>0.079 \\
\text { If } \beta 3 \text { is not significant, it is } \\
\text { completely mediation effect. }\end{array}$ \\
\hline & Mediator variable & & $\beta 4$ & Otherwise, it is partially \\
\hline & Organizational learning & & $0.764 * * *$ & \\
\hline
\end{tabular}

Note: $* * *, * *$ and $*$ indicate significant at the $0.001,0.01,0.05$ level, respectively (2-tailed).

\subsubsection{Empirical Results: PLS-based SEM Analysis}

Fornell and Cha (1994) conducted a series of in-depth research on PLS path analysis. They recommended PLS as a good method for maximizing extraction of variances and avoiding a series of problems such as incorrect understandings, uncertain factors, and distribution-violating hypotheses. PLS-based SEM analysis results also indicate that organizational learning mediates the relationship between entrepreneurial orientation and dynamic capabilities.

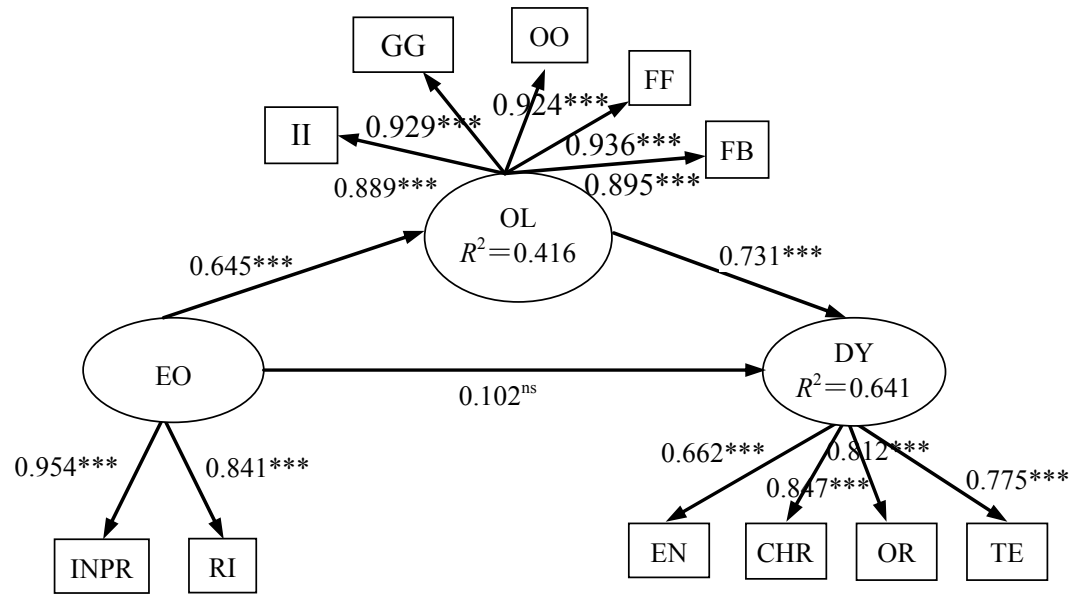

Fig. 2 PLS-based SEM Analysis Results

Note: $* * *, * *$ and $*$ indicate significant at the $0.001,0.01,0.05$ level, respectively (2-tailed). 


\section{Discussion}

This study examines the role of organizational learning between the relationship of entrepreneurial orientation and dynamic capabilities. The main purpose of the study is to find out how to build dynamic capabilities through entrepreneurial orientation and organizational learning. In doing so, we examine the relationships among entrepreneurial orientation, organizational learning and dynamic capabilities. The empirical evidence supports our hypotheses and indicates that entrepreneurial orientation can build dynamic capabilities in a rapidly changing environment but primarily do so through organizational learning improvement. The major findings and the implications are discussed as follows.

First, entrepreneurial orientation is divided into two dimensions through factor analysis, namely innovativeness and proactiveness strategy and risk-taking strategy. This shows that innovativeness and proactiveness strategy changes in shared common characteristics in the context of China. According to the market situation and imbalance in the development of a complex, diverse culture and unique characteristics of the Chinese background, it indicates that entrepreneurial orientation reflects different characteristics between emerging markets such as China and developed countries.

On the one hand, in the industries in which technology is relatively mature and highly competitive, such as garment industry and household appliances, it is only through proactive innovation, new product introduction, and technological upgrade than competitors, can competitive advantage be obtained. If business firms have always committed to the development of new products, transformation of existing products, as well as emphasizing product innovation, leading technology and research and development, they have the ability which makes them possess competitive attitude and new products, new management skills and technology to operate as the preferred means of competition.

On the contrary, in an emerging industry, as long as entrepreneurs are good at exploring and exploiting market opportunities, making good use of existing mature technologies, and taking risk in new customer segmentations, they will have more possibilities to succeed. At the initial stage of China's reform and opening-up, people are constrained by system of planned economy. It is easy to be successful for entrepreneurs who dare to try and break through the rules.

Second, dynamic capabilities can be divided into environmental sensing capabilities, change and renewal capabilities, technological and organizational flexibility capabilities through factor analysis, which further validate that dynamic capabilities can integrate resources, rebuild internal and external competence in order to amend operational capabilities in addressing a rapidly changing environment. Only with a keen insight into changes in environment and 
with support to update the ability to shape operational capabilities to adapt to the new environment, can companies eventually be accustomed to a dynamic, complex and changing environment.

Third, through correlation and regression analysis, innovativeness and proactiveness strategy in entrepreneurial orientation are significantly and positively related to dynamic capabilities. Innovativeness and proactiveness in entrepreneurial orientation will encourage business firms to enhance dynamic capabilities. This means that if a business firm has always committed to the development of new products, and transformation of existing products, it will concern changes in the industry, which significantly increase environmental sensing, renewal and flexibility capabilities as a result. In all, these kinds of behaviors will have significant positive effect on enhancement of dynamic capabilities. Although in correlation analysis, risk-taking strategy and dynamic capabilities showed simple Pearson correlation whereas in the subsequent regression analysis, risk-taking strategy was not entering in the regression equation.

Fourth, we propose that entrepreneurial orientation will have a positive effect on dynamic capabilities, and dynamic capabilities will be promoted through interactive learning of different levels such as individual, group, organization, forward and feedback. The development is bound to set up on all levels of learning so as to increase stock and flow of learning, change the portfolio of resources and knowledge, create new operational capabilities to adapt to new environment, and ultimately match internal resources with external environment. Empirical results confirmed the hypothesis, showing that innovation and proactiveness strategy were positively related to dynamic capabilities through the mediating role of organizational learning.

Without controlling the mediating variable, organizational learning and entrepreneurial orientation significantly influence dynamic capabilities. However, on the contrary, the case is totally opposite. This shows that the effect of independent variable on dependent variable is caused by the mediating variable, organizational learning, to a large extent. Then, organizational learning as mediator was put into equation together with independent variable of innovation and proactiveness strategy. The coefficients were not significant between innovation and proactiveness strategy and dynamic capabilities after introducing organizational learning. This indicated that organizational learning completely mediated the effect of innovation and proactiveness strategy on dynamic capabilities. Therefore, the study is very important to theory and practice of entrepreneurial orientation, organizational learning, and dynamic capabilities, and it is feasible for a business firm to promote its dynamic capabilities through organizational learning. 
In sum, entrepreneurial orientation and organizational learning play key roles in cultivating dynamic capabilities. Dynamic capabilities can be promoted through organizational learning in the context of entrepreneurial orientation strategy. The key agents such as entrepreneurs and senior managers have great motivations to constantly look for necessary resources and knowledge from networks, and then bring them back to the organization, which will be disseminated, reproduced and institutionalized in innovative and proactive organization. The process will continue and flow, and ultimately dynamic capabilities will be generated and promoted.

\section{Conclusion}

In conclusion, the dynamic capability theory shows that long-term competitiveness originates from the ability to create, accumulate, and utilize operational capabilities in turbulent, complicated, and ever-changing environments. Such dynamic environments require that companies possess not only particular operational capabilities but also dynamic capabilities to continuously upgrade their particular capabilities in a rapidly changing environment (Teece et al., 1997). This study, on the basis of literature review and extensive interviews, concludes that dynamic capabilities are composed of four components, including environmental sensing capabilities, change and renewal capabilities, organizational and technological flexibility capabilities. It further empirically validates them, and provides measure for dynamic capabilities so as to lay a solid foundation for companies to organically match their resources and capabilities to a changing environment (Andrews, 1987). These contributions enrich capabilities-related research in a strategic management field, and provide a foundation for future exploration on the relationships between dynamic capabilities and other variables.

In addition, it also shows that dynamic capabilities can be built through continuous organizational learning in the context of entrepreneurial orientation. These conclusions provide companies with theoretical guidance and practical path to establish dynamic and continuous competitiveness under a dynamic, complicated, and ever-changing environment. Further interpretations and elaborations are also given from perspectives of dynamic capabilities theory in this research, which finally combines previous research results, and proposes research framework. In this way, this study provides feasible solutions for companies to compile and implement their dynamic capabilities strategy.

Further research might be conducted in several directions. Replications of this study using different industry settings will help clarify the relationships identified in this study, and overcome the limited generalizability of the current study. That is to say, when we are validating the relationship model between three variables 
of entrepreneurial orientation, organizational learning and dynamic capabilities, effects of different industries are not taken into consideration. Subsequent research may also be dedicated to some particular characteristics of specific industries, compare between different industries and find out the effects of industry characteristics on the relationships among entrepreneurial orientation, organizational learning and dynamic capabilities.

Acknowledgements This work is supported by the Doctoral Dissertation in Soft Science Research Grant Program of Shanghai Science and Technological Development Funding (No. 200906004). We are grateful to the anonymous referees and editors for their constructive and helpful suggestions. Sincere thanks go to Guozhen Zhao for his kind suggestions on revision of this paper.

\section{References}

Ambrosini V, Bowman C (2009). What are dynamic capabilities and are they a useful construct in strategic management? International Journal of Management Reviews, 11(1): 29-49

Andrews K R (1987). The Concept of Corporate Strategy. Homewood, Ill: Irwin

Argyris C, Schon D (1978). Organizational Learning: A Theory of Action Perspective. Reading, MA: Addison-Wesley

Baker W B, Sinkula J M (1999). The synergistic effect of market orientation and learning orientation on organizational performance. Academy of Marketing Science, 27(4): 411-427

Barclay D, Higgins C, Thompson R (1995). The partial least squares (PLS) approach to causal modeling: Personal computer adoption and use as an illustration. Technology Studies, 2: 285-309

Belsley D A, Kuh E, Welsch R E (1980). Regression Diagnostics: Identifying Influential Data and Sources of Collinearity. New York: John Wiley

Bontis N (1998). Intellectual capital: An exploratory study that develops measures and models. Management Decision, 36(2): 63-76

Bontis N, Crossan M M, Hulland J (2002). Managing an organizational learning system by aligning stocks and flows. Journal of Management Studies, 39(4): 435-469

Burgelman R A (1983). Corporate entrepreneurship and strategic management: Insights from a process study. Management Science, 12: 1349-1364

Calantone R J, Cooper R G (1979). A discriminant model for identifying scenarios of industrial new product failure. Journal of the Academy of Marketing Science, 7(3): 163-183

Caloghirou Y (2004). Firm-specific effects on performance: Contrasting SMEs and large-sized firms. European Management Journal, 22(2): 231-243

Carmines E G, Zeller R A (1979). Reliability and Validity Assessment. Beverly Hills: Sage Publications

Cepeda G, Vera D (2007). Dynamic capabilities and operational capabilities: A knowledge management perspective. Journal of Business Research, 60(3): 426-437

Chandler A D (1962). Strategy and Structure: Chapters in the History of the American Industrial Enterprise. Cambridge, MA: MIT Press

Chin W W (1998). The partial least squares approach for structural equation modeling. In: Marcoulides G A (ed.), Modern Methods for Business Research. Lawrence Erlbaum Associates 
Christensen C M, Raynor M E (2003). The Innovator's Solution. Boston, MA: Harvard Business School Press

Churchill G A, Peter J P (1984). Research design effects on the reliability of rating scales: A meta-analysis. Journal of Marketing Research, 21: 360-375

Collis D J (1994). Research note: How valuable are organizational competence. Strategic Management Journal, 15: 143-152

Covin J G, Green K M, Slevin D P (2006). Strategic process effects on the entrepreneurial orientation sales growth rate relationship. Entrepreneurship Theory and Practice, 30: 57-81

Covin J G, Slevin D P (1989). Strategic management of small firms in hostile and benign environments. Strategic Management Journal, 10(1): 75-87

Covin J G, Slevin D P (1991). Conceptual model of entrepreneurship as firm behavior. Entrepreneurship Theory and Practice, 16(1): 7-25

Crossan M, Lane H W, White R E (1999). An organizational learning framework: From intuition to institution. Academy of Management Review, 24(3): 522-538

Crossan M, Nicolini M (2000). Organizational learning: Debates past, present and future. Journal of Management Studies, 37(6): 783-796

D'Aveni R A (1994). Hyper-competition: Managing the Dynamics of Strategic Manoeuvring. New York: The Free Press

Dess G G, Ireland R D, Zahra S A, Floyd S W, Janney J J, Lane P J (2003). Emerging issues in corporate entrepreneurship. Journal of Management, 29(3): 351-378

Eisenhardt K M, Tabriz B N (1995). Accelerating adaptive process: Product innovation in the global computer industry. Administrative Science Quarterly, 40(1): 84-110

Eisenhardt K M, Martin M (2000). Dynamic capabilities: What are they? Strategic Management Journal, 21(10): 1105-1121

Fiol C M, Lyles M (1985). Organizational learning. Academy of Management Review, 10: 803-813

Fornell C, Larcker D F (1981). Evaluating structural equation models with unobservable variables and measurement error. Journal of Marketing Research, 18(2): 39-50

Fornell C, Cha J (1994). Partial least squares. In: Bagozzi R P (ed.), Advanced Methods of Marketing Research. Cambridge, MA: Blackwell Business, 52-78

Goh S, Richards G (1997). Benchmarking the learning capability of organizations. European Management Journal, 15(5): 575-583

Griffith D A, Harvey M G (2001). A resource perspective of global dynamic capabilities. Journal of International Business Studies, 32(3): 597-606

Hamel G, Prahalad C K (1994) Competing for the Future. Boston, MA: Harvard Business School Press

Helfat C E, Peteraf M A (2003). The dynamic resource-based view: Capability lifecycles. Strategic Management Journal, 24(10): 997-1010

Huber G P (1991). Organizational learning: The contributing processes and the literatures. Organization Science, 2(1): 88-115

Hult G, Thomas M, Ferrell O C (1997). A global learning organization structure and market information processing. Journal of Business Research, 40: 155-166

Iansiti M, Clark K B (1994). Integration and dynamic capability: Evidence from product development in automobiles and mainframe computers. Industrial and Corporate Change, 3(3): 557-605

Jantunen A, Puumalainen K, Saarenketo S, KylÃheiko K (2005). Entrepreneurial orientation, dynamic capabilities and international performance. Journal of International Entrepreneurship, 3: 223-243 
Khandwalla P N (1977). The Design of Organizations. New York: Harcourt Brace Jovanovich

Lawson B, Samson D (2001). Developing innovation capability in organizations: A dynamic capabilities approach. International Journal of Innovation Management, 5(3): 377-400

Lumpkin G T, Dess G G (1996). Clarifying the entrepreneurial orientation construct and linking it to performance. Academy of Management Review, 21(1): 135-73

Lumpkin G T, Dess G G (2001). Linking two dimensions of entrepreneurial orientation to firm performance: The moderating role of environment and industry life cycle. Journal of Business Venturing, 16(5): 429-451

Miller D (1983). The correlates of entrepreneurship in three types of firms. Management Science, 29(7): 770-791

Miller D, Friesen P H (1982). Innovation in conservative and entrepreneurial firms: Two models of strategic momentum. Strategic Management Journal, 3(1): 1-25

Morris M H, Kuratko D F (2001). Corporate Entrepreneurship: Entrepreneurship Development within Organization. New York: Harcourt Press

Naman J L, Slevin D P (1993). Entrepreneurship and the concept of fit: A model and empirical tests. Strategic Management Journal, 14: 137-153

Nelson R R, Winter S G (1982). An Evolutionary Theory of Economic Change. Cambridge, Mass: Belknap Press of Harvard University Press

Nonaka I, Takeuchi H (1995). The Knowledge Creating Company. New York: Oxford University Press

Nunnally J C (1978). Psychometrics Methods. New York: McGraw-Hill Company

Penrose E T (1959). The Theory of Growth of the Firm. Oxford: Basil Blackwell Publisher

Phillips L W (1981). Assessing measurement error in key informant reports: A methodological note on organizational analysis in marketing. Journal of Marketing Research, 18(4): 395-415

Podsakoff P M, Organ D W (1986). Self-reports in organizational research: Problems and prospects. Journal of Management, 12(4): 531-544

Prahalad C K, Hamel G (1990). The core competencies of the corporation. Harvard Business Review, 66: 79-91

Sambrook S, Roberts C (2005). Corporate entrepreneurship and organizational learning: A review of the literature and the development of a conceptual framework. Strategic Change, 14(3): 141-155

Shimp T A, Sharma S (1987). Consumer ethnocentrism construction and validation of the CETSCALE. Journal of Marketing Research, 27(8): 280-289

Sinkula W, Baker E, Thonams N (1997). A framework for market-based organizational learning: Linking values, knowledge, and behavior. Journal of the Academy of Marketing Science, 25(4): 305-318

Sirmon D G, Hitt M A (2003). Managing resources: Linking unique resources, management, and wealth creation in family firms. Entrepreneurship Theory \& Practice, 27(4): 339-358

SubbaNarasimha P N (2001). Strategy in trubulent environments: The role of dynamic competence. Managerial and Decision Economics, 22: 201-212

Teece D J, Piano G (1994). The dynamic capabilities of firms: An introduction. Industry and Corporate Change, 3: 537-555

Teece D J, Piano G, Shuen A (1997). Dynamic capabilities and strategic management. Strategic Management Journal, 18(7): 509-533

Teece D J (2007). Explicating dynamic capabilities: The nature and microfoundations of (sustainable) enterprise performance. Strategic Management Journal, 28(4): 1319-1350

Tsoukas H, Mylonopoulos N (2004). Organizations as Knowledge Systems: Knowledge, 
Learning and Dynamic Capabilities. New York: Palgrave Macmillan

Wiklund J (1999) The sustainability of the entrepreneurial orientation-performance relationship. Entrepreneurship Theory and Practice, 24: 37-48

Wiklund J, Shepherd D (2005). Entrepreneurial orientation and small business performance: A configurational approach. Journal of Business Venturing, 20: 71-91

Winter S G (2003). Understanding dynamic capabilities. Strategic Management Journal, 24(10): 991-995

Zahra S A, Covin J G (1995). Contextual influences on the corporate entrepreneurship-performance relationship: A longitudinal analysis. Journal of Business Venturing, 10(1): 43-58

Zahra S A, Nielsen A P, Bogner W (1999). Corporate entrepreneurship, knowledge, and competence development. Entrepreneurship: Theory and Practice, 23(3): 169-190

Zahra S A, George G (2002). The net-enabled business innovation cycle and the evolution of dynamic capabilities. Information Systems Research, 13(2): 147-151

Zahra S A, Sapienza H J, Davidsson P (2006). Entrepreneurship and dynamic capabilities: A review, model and research agenda. Journal of Management Studies, 43(4): 917-955

Zollo M, Winter S G (1999). From organizational routines to dynamic capabilities. Working Paper of the Reginald H. Jones Center, the Wharton School University of Pennsylvania

Zollo M, Winter S G (2002). Deliberate learning and the evolution of dynamic capabilities. Organization Science, 13(3): 339-351

Zott C (2003). Dynamic capabilities and the emergence of intra-industry differential firm performance: Insights from a simulation study. Strategic Management Journal, 24(2): $97-112$

李兴旺 (Li Xingwang) (2006). 动态能力理论的操作化研究: 识别、架构与形成机制 (Dynamic Capabilities Theory: Identification, Construction and Formation Mechanism). 北京：经济科 学出版社, 52-67

贺小刚, 李新春, 方海鹰 (He Xiaogang, Li Xinchun, Fang Haiying) (2006). 动态能力的测量与 功效: 基于中国经验的实证研究 (Measurement and efficiency of dynamic capabilities: An empirical study in China). 管理世界, (3): 94-103, 113 